\title{
Rola św. Jana Pawła II w życiu ks. prof. Jerzego Bajdy
}

Ks. bp Wojtyła wrócił z Soboru przejęty jego treścią i zorganizował spotkanie teologów, którzy mieli opracować materiał dla Pawła VI na temat etyki małżeńskiej. Do tych teologów, zaproszonych przez biskupa Wojtyłę, należał ks. Jerzy Bajda.

Po tym spotkaniu zorientowałam się, że to jest Ksiądz, który doskonale chwycił to, o co chodziło naszemu Biskupowi. Ks. bp Wojtyła od początku zajmował się problematyką małżeńską, a właściwie etyki małżeńskiej, co w pewnym sensie było zasługą kardynała Stefana Sapiehy, który powierzył mu dwie funkcje: prowadzenie duszpasterstwa studentów wyższych uczelni i duszpasterstwa lekarzy. Wszystko w kontekście wykładów etyki. To był etyk i pierwsza jego działalność odnosiła się już do kontaktów prowadzących do małżeństwa. Jego monograficzny wykład na KUL-u, wydany potem jako „Miłość i odpowiedzialność", stanowił podstawę tego, co było właściwie treścią całego działania duszpasterskiego.

Jak wiadomo Paweł VI wydzielił Komisję do spraw Rodziny i w sposób szczególny powierzył tę sprawę biskupowi krakowskiemu, który rzeczywiście brał udział w powstaniu dokumentu posoborowego „Humanae vitae”. Do powstania tej encykliki przyczynił się między innymi Ks. Jerzy Bajda. Wtedy właśnie ks. bp Wojtyła zauważył tego teologa w sposób, który owocował potem ciągłą współpracą. 
Muszę powiedzieć, że przez całe życie ks. Bajda pomagał biskupowi Wojtyle i mnie też. W pewnym momencie uczestniczyliśmy w wielkiej walce, która jest aktualna do dzisiaj. W walce o świętość małżeństwa, o podstawę etyki małżeńskiej, którą Paweł VI podyktował w „Humanae vitae”.

Niektórzy z Państwa wiedzą, a w każdym razie powinni wiedzieć, że encyklika spotkała się ze sprzeciwem. Część ludzi zarówno wierzących jak i niewierzących, a nawet księży, a nawet biskupów nie zgodziła się z treścią papieskiego przesłania. Była i cały czas trwa walka o zaakceptowanie nauki Pawła VI o płodności ludzkiej. Dziennikarze spodziewali się, że papież zaakceptuje nowy środek, który wynalazła wówczas medycyna, mianowicie hormony, które działały przeciwko poczęciu, przeciwko zapłodnieniu. Antykoncepcja została potraktowana jako temat wyjątkowo kontrowersyjny, bo wielu ludzi uważa, że nie ma innego wyjścia, że Kościół zmusza ludzi do rodzenia dzieci. Jest kwestią oczywistą, że płodność ludzka musi być sterowana, poddana rozsądkowi i sumieniu. Równocześnie jest prawem naturalnym i ludzie muszą się do tej sprawy odnieść z szacunkiem.

Walka z antykoncepcją jest sprawą aktualną dla Kościoła do dzisiaj i do dzisiaj nie wszyscy to rozumieją. Ks. Jerzy Bajda uchwycił problem natychmiast. Rzecz ciekawa, że reagował tak jak Karol Wojtyła. Po paru latach obserwowania tej walki, w której ja też brałam czynny udział, zarówno Paweł VI, jak i potem Jan Paweł II zaangażowali również lekarzy, bo problem małżeństwa to także problem medycyny. W tej walce do dzisiaj nie ma jednoznacznych rozstrzygnięć. Ludzie wciąż nie rozumieją dlaczego, tak jak powiedział Jan Paweł II, antykoncepcja jest grzechem przeciwko pierwszemu Bożemu przykazaniu, grzechem pychy człowieka, szczególnie mężczyzny. Część księży także nie rozumiała. Gdy kiedyś zapytałam ks. bpa Wojtyłę, czy któryś z księży rozumie jego filozofię, personalizm i teologię ciała, bez wahania odpowiedział: „Jeden, ks. Jerzy Bajda”. I rzeczywiście, on nie tylko rozumiał problem. Obserwując życie obu tych kapłanów, zarówno arcybiskupa, potem kardynała, wreszcie papieża Karola Wojtyły, jak i ks. Jerzego Bajdy, widziałam, że nadają na tej samej fali. Oczywiście prawda jest jedna i ludzie, którzy dążą do prawdy, wreszcie się spotykają i mają różne podejścia, i różne rozumienie. To nieprawdopodobne, a jednak prawdziwe, że ci dwaj całkowicie odmienni w usposobieniu i charakterze kapłani tak doskonale i tak podobnie rozumieli problem etyki małżeńskiej, problem ludzkiej miłości. 
Ks. Bajda był niezawodny. Na wszystkie pytania, z którymi borykały się duszpasterstwa: Rodzin, Młodzieży czy Lekarzy, Ksiądz Jerzy dawał doskonałą odpowiedź. Był jedynym teologiem i profesorem, który rychło podejmował temat i jeśli obiecywał opracować jakiś temat, to zawsze dotrzymywał terminu (a bywało nawet, że dostarczył tekst przed terminem). Przede wszystkim jednak dawał argumenty podstawowe, dogłębnie przekonywające, nie do zbicia. Jedynym problemem Księdza Jerzego z nauczaniem młodzieży było to, że pokazywał problem od najgłębszych podstaw, co powodowało, że wypowiadał się długo i trudno. Często oskarża się filozofów i teologów, że mówią specjalistycznym językiem. Studenci zaś skarżyli się, że ks. Bajda mówi za długo, choć zarazem jego wypowiedzi były wyczerpujące, klarowne, jednoznaczne i w pewnym sensie bardzo odważne. Każdy problem przedstawiał w sposób zrozumiały i w oparciu o naukę Kościoła. To był kapłan nieprawdopodobnie płodny, równocześnie bardzo skromny, taktowny wrażliwy, delikatny, nienarzucający się nikomu., Nie dążył do kariery, nie zależało mu na tym, żeby być na pierwszym miejscu.

Prasa poruszyła trudny problem antykoncepcji. Zadzwoniłam do Księdza Jerzego, że są potrzebne argumenty, a on natychmiast napisał artykuł. Nieraz oskarżamy kapłanów, którzy powinni zajmować się nauczaniem, że wypowiedzi Kościoła są spóźnione, pojawiają się, jak już problem narośnie. Ks. Bajda był na bieżąco, potrafił polemizować z dziennikarzami, lekarzami, teologami, małżeństwami. Gdy pojawiał się trudny problem, należało pytać ks. Bajdę. On pozwalał się angażować do pracy z młodzieżą, małżeństwami, księżmi, klerykami, nawet politykami. Kiedyś obradowała Komisja Biologiczna, były spotkania z posłami; ks. Bajda formułował argumenty. Kiedy ks. kard. Wojtyła chciał zrobić sesję dla księży, przekonać ich, że encyklika Humanae vitae obowiązuje w sumieniu, głównym wykładowcą został Ksiądz Jerzy.

Lekarze zapisują antykoncepcję, lekarze katoliccy nie rozumieją, że togrzech. Pchają małżeństwa do tego grzechu. Ks. Jerzy Bajda pisze, dlaczego antykoncepcja jest grzechem. Mało tego, potrafi napisać świetny artykuł na temat ludzkiego oblicza medycyny. To, co do dzisiaj jest problemem, on podjął już wtedy. Dzisiaj wszyscy już wiedzą, że medycyna przeszła na stronę, która zajmuje się weterynarią i traktuje człowieka tak samo jak zwierzęta. Ks. Bajda pokazywał to już wtedy, bo to jest kwestia zrozumienia filozofii. W personalizmie Karola Wojtyły człowiek nigdy nie jest przedmiotem, nie może być traktowany jak przedmiot. Ksiądz Jerzy godność osoby ludzkiej 
rozumiał dokładnie tak samo jak Ksiądz Karol. To pokrewieństwo ducha. Co więcej, ks. Bajda był wrażliwy na poezję, a Karol Wojtyła było filozofem, teologiem i poetą. Mieli taką samą wrażliwość.

Kiedy oboje z mężem zostaliśmy członkami Papieskiej Rady do spraw Rodziny, chciałam włączyć do działalności tej Rady ks. Jerzego Bajdę. Spowodowałam, że zaproszono go do Rzymu, przygotowałam jego referat $w$ trzech językach kongresowych, ale niespodziewanie natrafiłam na trudność, której nie przewidywałam. Ks. bp Majdański nie chciał puścić Księdza Jerzego z Polski, nie oddał go. W pewnym sensie to był zysk dla Polski, że on został w Łomiankach, ale mnie brakowało księży na spotkaniach zarówno Papieskiej Rady do spraw Rodziny, jak i Papieskiej Akademii „Pro Vita”. Brakowało teologów tak dobrze rozumiejących antropologię Karola Wojtyły jak Ksiądz Jerzy. Jemu zależało na tym, żeby pokazać ludziom problem. Wszyscy, i ks. Karol Wojtyła, i ks. Jerzy Bajda, i ja, wiedzieliśmy, że konieczna jest współpraca z lekarzami. Ks. Karol Wojtyła nie tylko dlatego był przejęty lekarzami, że miał brata lekarza, ależ też uważał, że medycyna zagraża świętości rodziny. Chciał zmienić mentalność lekarzy, którzy zaakceptowali wypisywanie recept na środki antykoncepcyjne i dopuścili aborcję, najpierw chirurgiczną, a potem farmakologiczną.

Ks. Jerzy Bajda podejmował wszystkie sprawy, z którymi zwracałam się do niego, gdy potrzebowałam autorytetu teologa. Pewna farmaceutka napisała do mnie, że nie rozumie, dlaczego Kościół zabrania jej sprzedaży pigułek antykoncepcyjnych. Posłałam list do ks. prof. Bajdy, a on nie tylko napisał artykuł, ale też odpowiedział listownie tej pani, która miała wątpliwości. Kiedyś pomyślałam, że łatwiej będzie wychować kadrę lekarzy, jeśli zajmiemy się studentami medycyny. Zorganizowałam, za zgodą i akceptacją biskupa krakowskiego, seminarium kleryków i medyków, które nazwałam „Cler Med”. Spotkania odbywały się co tydzień w środę w okresie od września do czerwca, w salonie kardynała, który dał go na salę wykładową i tam spotykała się gromadka zainteresowanych kleryków i medyków z szóstego roku; niektórzy z tej grupy już nie żyją. Ks. Bajdę zaprosiłam do współpracy.

W każdą środę były przedstawiane do dyskusji dwa referaty na ten sam temat, jeden opracowany przez medyka, a drugi przez kleryka. Wychodziłam z założenia, że klerycy wiedzą coś o duszy ludzkiej, a lekarze o ciele, i że powinni się tą wiedzą ze sobą podzielić, bo człowiek jest złożony z ciała i duszy. Karol Wojtyła uważał, że każdy ksiądz, który zajmuje się duszpasterstwem 
małżeństw, musi mieć pomoc lekarza, a każdy lekarz, który prowadzi poradnię rodzinną i małżeńską, musi mieć wsparcie księdza.

W jednym pokoju, który mi dał ze swego apartamentu ks. kard. Wojtyła, siedziałam ja, a w drugim kapłan. Po rozmowie z małżeństwem mogłam od razu skierować tych ludzi do pokoju obok, żeby mogli się wyspowiadać (ogromna ilość konfliktów małżeńskich to są po prostu skutki grzechów przeciwko czystości małżeńskiej). Czystość jako dziewictwo ludzie mniej więcej rozumieją, natomiast czystość małżeńska nie jest zrozumiała. Małżonkowie bardzo często tracą właściwe rozeznanie, to problem formacji sumienia. Seminarium dla medyków i kleryków było formacją sumienia, bo człowiek musi podejmować właściwe wybory, jak mówił Karol Wojtyła, „W sumieniu dobrze uformowanym”.

Ks. Jerzy Bajda oddziaływał na ludzkie sumienie. Był prawdziwym duszpasterzem, a takich jest niewielu. To zasadnicza trudność, ponieważ konflikty małżeńskie wymagają czasem pomocy psychologa, niekiedy lekarza, jednak zawsze wymagają pomocy teologa, ponieważ chodzi o problemy ludzkiego sumienia i ludzkiej odpowiedzialności za rzecz najważniejszą - życie ludzkie. W tym działaniu ks. Jerzy Bajda był niezastąpiony: podejmował wszystkie inicjatywy, polemizował na łamach prasy, podejmował dyskusje, nie bał się. Natomiast w traktowaniu osób był delikatny, co też łączyło go z ks. Karolem Wojtyłą. Twardy i niewzruszony w zasadach, a i wrażliwy delikatny w postępowaniu. To jest zasada działania Chrystusa: potępiać grzech, a kochać grzesznika.

Przez całe życie korzystałam z pomocy ks. Jerzego Bajdy, przy czym on nigdy się tym nie chwalił. Był niezawodny, nigdy nie mówił, że nie ma czasu. Nieraz zasięgałam opinii, szukałam pomocy u kapłanów; i czasem napotykałam na trudności: owszem, ksiądz niby mógł pomóc, ale niestety miał inne zajęcia i nie dysponował wolnym czasem. Ks. Bajda nigdy nie powiedział, że nie ma czasu, nigdy nie odmówil, zawsze był do dyspozycji. Wydawało się, że jego czas rozciąga się, jak to zawsze jest u ludzi, którzy są dobrymi organizatorami i mają czas na rzeczy, które są ważne. W Humanae vitae Paweł VI napisał do biskupów, że mają problem małżeństwa i rodziny postawić na pierwszym miejscu w swoim działaniu duszpasterskim. Nie wszyscy biskupi i nie wszyscy księża to zrealizowali, a ci dwaj zarówno: ks. Jerzy Bajda, jak i ks. Karol Wojtyła problem świętości małżeństwa, problem świętości i miłości ludzkiej naprawdę uważali za rzecz najważniejszą. Chciałoby 
się, żeby takich kapłanów było więcej. Karol Wojtyła był zapalonym sportowcem, pływał, chodził po górach. Ks. Jerzy Bajda nie popisywał się takimi wyczynami, jak inni księża zajmujący się młodzieżą, natomiast nigdy nie odmawiał, gdy ktoś prosił go o pomoc. Była to pomoc efektywna. Ks. Bajda potrafił w krótkim czasie przygotować materiał zarówno dla lekarzy, księży, jak i dla biskupów, a ponadto był gotów przyjechać. Potem, gdy wyjechał do Warszawy i nie było go tak blisko Krakowa, to jednak za każdym razem, gdy ks. Karol Wojtyła urządzał sesję naukową dla lekarzy ważną dla tematu rodziny, ks. Bajda był do dyspozycji.

Byłam pewna jego przyjaźni. Był to człowiek z pewnym dystansem wynikającym z szacunku dla wszystkich ludzi. Nie spoufalał się jak inni księża, którzy pozwalają sobie poklepać świeckiego po ramieniu. Ks. Bajda kapłaństwo pokazywał jako sposób realizowania życia, który trzeba szanować. Zresztą szacunek dla kapłaństwa to jest cecha narodu polskiego. Obserwuję teraz narastający antyklerykalizm, wywołany sztucznie w Polsce. Zarazem nie każdy kapłan potrafi się tak zachować, że narzuca się szacunek dla kapłaństwa. Ks. Bajda był taki właśnie, że było wiadomo, że to jest ksiądz, następca Chrystusa na ziemi. I jest to, w moim pojęciu, jedyne słuszne ksiądz nie może upodabniać się do zwykłych chłopaków, musi się odróżniać. Oczywiście dobrze jak odróżnia się koloratką i nie ukrywa, że jest kapłanem, ale to nie jest kwestia sposobu ubioru czy sposobu samego bycia, takiego czy innego, tylko tego, czy dany człowiek promieniuje. Najważniejszym zadaniem duszpasterzowania ks. Karola Wojtyły było pokazanie światu duchowości. On chciał pokazać światu, że tożsamość człowieka to duchowość. Otóż prawdziwy kapłan żyjący Bogiem tym promieniuje i to właśnie czułam w odniesieniu do tych dwóch księży. W obecności ks. Karola Wojtyły człowiek zawsze miał świadomość, że Bóg jest blisko. Dokładnie taką samą aurę tworzył ks. Jerzy Bajda - taktowny, delikatny, równocześnie stanowczy, powiedziałabym jednoznaczny: żadnych ustępstw na rzecz kompromisu, po prostu jasne stwierdzenie, że prawda jest jedna. Stąd bardzo szybko zrozumiałam, że to, co ks. Karol Wojtyła powiedział o ks. Jerzym Bajdzie, że jedynie on zrozumiał do końca jego myśl, było prawdą, było zyskiem, i to nas złączyło. Uważam, że trzeba żeby tę postać, tego kapłana, bardziej pokazać, prześledzić jego życiorys, jego działania. 